\title{
Reforma Administrativa Plano de Execução
}

\author{
INTRODUÇÃO
}

A

opinião pública parece disposta não só a aceitar, senão a exigir que o Govêrno proceda, sem mais delongas, às chamadas reformas de base. Os grupos mais atuantes - os politicos, escritores, artistas, professôres, os titulares das várias profissões liberais, ornalistas e varios outros - vão-se tornando pregoeiros cônscios dêsse imperativo nacional.

Dentre as reformas chamadas de base, a agrária é considerada premente. No momento em que os problemas de abastecimento se agravam em todo o território nacional, sua necessidade parece mais aguda.

Para os que assim pensam, um dos efefitos imediatos da $\mathrm{Re}$ forma Agrária seria o aumento de produção de gêneros alimenticios e matérias-primas de origem agrícola. Segundo êles, não se trata apenas do problema social de melhorar o quinhão de segurança econômica do homem esquecido - o trabalhador rural; trata-se, também, do problema econômico de abreviar a utilização de vastas glebas brasileiras que permanecem improdutivas.

E' inegável que o trabalhador rural, sem bens de raiz, que labuta pela vida lavrando terras alheias, au delà da proteção do seguro social, representa um problema nevrálgico do Brasil contemporâneo. E a filosofia politica hoje perfilhada pela maioria dos brasileiros já reluta em endossar o desnivel de rendas que se verifica no País: ao passo que alguns poucos detêm muito, mais do que necessitam, a imensa maioria compõe-se de familias e individuos em luta com o problema do pão e da casa, e milhões possuem apenas o próprio corpo.

Dado o vigoroso crescimento demográfico do Brasil, a agricultura tradicionalista terá progressivas dificuldades para fazer face aos acréscimos anuais da demanda de gêneros alimenicios e matérias-primas de origem agrícola. "A Reforma Agrária - diz o editorial da Revista do Serviço Público do último trimestre de 1962 - preveniria crises de abastecimento e introduziria novos elementos de equilibrfo na sociedade brasileira. Se levada a efeito sob medida para o Brasil, teria reflexos na produção de bens e 
na distribuição dos benefícios econômicos. As desigualdades de rendas entre as diterentes camadas sociais e as oscilações de renda das classes menos favorecidas, por exemplo, poderiam ser grandemente mitigadas por meio de uma Reforma Agrária bem formulada e bem administrada".

Em sua complexidade, a Reforma Agrária envolve aspectos sociais, econômicos, administrativos e outros. A redistribuição de terras, pura e simples, não fará o milagre de multiplicar a produção. Diversas medidas complementares, onerosas e lentas, serão condicionantes do bom êxito de qualquer Reforma Agrária.

Em seu famoso ensaio, "O Estudo de Administração", W. WILSON afirmava, em 1887, que "cada vez se torna mais difícil cumprir do que elaborar uma Constituição". Mutatis mutandis: é muito mais dificil administrar do que formular uma Reforma Agrária. Comenta a Revista do Serviço Público no mesmo editorial: " $E$ ' difícil fazer a Reforma Agrária. Difícil, porém, porque não se trata apenas de votar uma lei, mas especialmente de implementar, isto é, de executar, de administrar a Reforma".

Outra reforma não menos premente é a do sistema tributário, incluindo o aparelho fiscal. Dois decênios de inflação, acelerada em grande parte pela conjuntura dificil em que tem operado o Govêrno Federal, indicam a inadiabilidade da Reforma Fiscal e Tributária.

Pressionado pelos reclamos e exigências dos diferentes segmentos da população, o Govêrno brasileiro vê-se a braços com centenas de questões instantes, muitas delas relegadas pelas gerações passadas, e cuja solução depende de recursos consideráveis, os quais o Govêrno só poderá levantar se dispuser de uma estrutura fiscal atualizada. Cumprindo-lhe, de um lado, ocorrer a gastos enormemente ampliados pelo crescimento demográfico, e, de outro lado, fazer frente a problemas novos, como os decorrentes da industrialização e do desenvolvimento econômico, o Govêrno Federal não tem contado com outros recursos, além do endividamento e a emissão de papel-moeda, para atender ao aumento incessante das despesas públicas. Se dispuséssemos de um sistema tributário moderno, a cargo de um aparelho fiscal eficiente, que tornasse impossivel, ou pelo menos inequìvocamente perigosa, a prática da sonegação de impostos, do contrabando e do descaminho, o ritmo de emissão de papel-moeda teria sido consideràvelmente menor, $\mathrm{e}$ as condições financeiras do País talvez fôssem tranqüilas, quem sabe, até risonhas.

A necessidade de incrementar substancialmente a receita federal, a fim de habilitar o Govêrno a fazer face ao aumento incoercível das despesas, coloca a reforma fiscal e tributária na categoria de reforma de base. 
Mas a Reforma T'ributária pressupõe um complexo de práticas administrativas. As melhores leis tributárias elaboradas pelos melhores economistas e legisladores produzirão resultados mediocres, se não forem canalizadas para a prática, se não forem competentemente administradas. $E^{\prime}$ na fase administrativa, especialmente, que as leis tributárias revelam a sabedoria e sagacidade do legislador. Se a administraçáo fôr canhestra, arcaica, rombuda, ou corrupta, nenhuma lei tributária provoca os resultados previstos, ainda quando elaborada por uma plêiade de Licurgos de moderna espécie. O bom êxito da Reforma Tributária depende, assim, diretamente, do realismo e simultaneidade da Reforma Administrativa.

O revigoramento e expansão do sistema educacional, para que êste passe a treinar e preparar, em escala trepidante, os contingentes de centenas de milhares de especialistas e profissionais de que o Brasil necessita como fatôres insubstituivels de progresso econômico e social, por sua vez constitui outro problema cuja solução pede reforma imediata. Calcula-se que, para mover harmoniosamente as várias frentes de sua civilização, o Brasil necessita de cêrca de 1.500 .000 indivíduos de nivel universitário ou eqüivalente. Sabendo-se que o número de indivíduos que satisfazem essa condição atualmente orça por 200.000 , é inevitável a conclusão de que urge fazer algo relativamente ao sistema educacional, a fim de que êste possa formar para o Brasil, no menor periodo de tempo possivel, as categorias de profissionais, de cientistas e especialistas, de que carecemos para assegurar o impulso e o equilibrio de nosso progresso econômico e social.

Várîos outros problemas exigem, também, soluções imediatas: a contenção da inflação, o disciplinamento das remessas de lucros das emprêsas estrangetras que exploram o comércio e a indústria no Brasil; a mudança definitiva do Govêrno para a nova Capital; a fixação da política exterior do Brasil; a construção, melhoramento e aproveitamento racional das vias de transportes e dos sistemas de comunicação, para estimular o comércio de pessoas, idéias e coisas, ao longo e através do território nacional etc.

E a conclusão inescapável, a que conduz uma análise objetiva da atual conjuntura brasileira, é a de que a Reforma Administrativa deve figurar no rol das mais urgentes. Sem que o sistema administratıvo da Unão seja modernizado, afeiçoado às exigências atuais, habilitando o Govêrno Federal a interpretar competentemente os fatos e tomar prontamente, nos lugares e momentos adequados, as providências convenientes; em outras palavras, sem que o sistema administrativa da União seja transformado em instrumento idôneo de captação, análise e solução 
dos problemas nacionais, nenhuma das outras reformas de base poderá ser levada a bom têrmo.

Consoante já se tem afirmado, a máquina administrativa com que o Govêrno da União conta para enfrentar as mil e uma responsabilidades que o assoberbam é inadequada, anárquica e obsoleta. Muitas das crises, grandes e pequenas, que ùltimamente têm abalado os Podêres Públicos, emanam da incompetência e da ineficiência da administração. A inflação, por exemplo, é o mais ativo fermento do desassossêgo social do Brasil de nossos dias. Cumpre ao Govêrno contê-la, sob pena de convulsões sociais catastróficas. E não é apenas para conjurar precipitados sociais de conseqüências imprevisiveis que se impõe ao Govêrno dominar a inflação. Cumpre contê-la, repita-se, principalmente para proteger o homem brasileiro, a criança brasileira, a familia brasileira contra as injustiças e crueldades decorrentes da alta desabalada do custo de vida. No grau a que chegou no Brasil, a inflação é causa de males coletivos desnecessários e evitáveis, que afetam a grande maioria do povo. Julgar a inflação, porém, é tarefa administrativa, e das mais complexas. Como sanear a moeda, estabilizar o cruzeiro, sustar a corrida dos preços e dos salários, e manter o País em desenvolvimento, sem um sistema administrativo bem articulado, flfexivel, sob o comando de administradores decididos e experimentados?

Em suma: o exame meticuloso das presentes condições brasileiras identificaria, no âmago de cada problema que nos aflige, uma falha administrativa. A precariedade das utilidades públicas, dos serviços de eletricidade, água e esgotos, transportes e telefones urbanos; a ineficiência das escolas e dos serviços de saúde pública; as dificuldades do abastecimento; tudo isso, e muito mais, decorre, em grande parte, do estágio retardatário, contemporâneo do fim do século passado, em que ainda se arrastam a estrutura, o funcionamento e os métodos administrativos do serviço público brasileiro.

Se a máquina administrativa federal fôsse fluente, econômica, pronta na captação dos problemas e dos fatos, rápida nos diagnósticos, eficiente nas providências requeridas ou aconselháveis, a civilização brasileira estaria em nivel superior àquele em que se encontra. Ao passo que a presença do Brasil no mundo deixou de ser ùnicamente geográfica, e passou a impor-se, cada vez mais, pelas nossas magnificas performances em vários ramos de atividades competitivas e civilizadoras, a administração pública, de um modo geral, permanece decênios atrás, teimando em perpetuar-se no caldo de cultura do comêço do século. 
Vale a pena reproduzir, do referido editorial da Revista do Serviço Público, mais os dois excertos seguintes:

“O Brasil possui, em abundância, os ingredientes de cultura e civilização com que outros países construiram ou estão construindo a própria grandeza. Senão, vejamos: somos um país continental, o quinto do mundo em área; somos o oitavo em população; temos um território bem aquinhoado de riquezas naturais, matérias-primas, rios, florestas, terras cultiváveis, vários tipos de clima. Já somos, também, o pais mais industrializado da América Latina. Na arquitetura, no urbanismo, na pintura, na música, na literatura, na medicina, na física, nos esportes e em outros campos de atividade, o Brasil está aparecendo como nôvo astro nos horizontes do mundo - o Brasil está adquirindo e afirmando uma personalidade internacional cada vez mais nítida, que os demais países já não podem ignorar. Em suma, a conjuntura brasileira favorece a precipitação daquilo a que a imprensa tem chamado "nossa emancipação econômica" e que simboliza o ideal da atual geração de brasileiros.

"Dentre as debilidades, inadequações e arcaísmos, de que o País se deve desvencilhar, para acelerar o ritmo de seu desenvolvimento ecunômico e social e resolver bem um a um os chamados problemas nacionais, de acôrdo com uma escala de prioridade selecionada realisticamente, destaca-se o atual sistema administrativo. A estrutura, o funcionamento, os métodos de trabalho, a própria ambiência do serviço público brasileiro - em todos os niveis de govêrno - devem ser revistos, atualizados, modernizados, mediante uma reforma corajosa, urgente e profunda".

Urge renovar, pois, a máquina administrativa, modificar-lhe a estrutura, retificar-lhe o funcionamento, substituir-lhe os métodos e normas de trabalho. Urge dar ao Brasil um sistema administrativo compativel com seus anseios de progresso, e tecnològicamente contemporânec de sua arquitetura, de suas belas-artes, de sua indústriu e de seu esporte.

Estas considerações demonstram que a Reforma Administrativa, tão premente quanto as que mais o sejam, deve tratar-se em pé de igualdade com as demais reformas de base.

Outro não é o entendimento do Govêrno. Com efeito, o Presidente da República declara, no artigo $1^{\circ}$ do Decreto número 51.705 , de 14 de fevereiro de 1963 , que dispóe sôbre o escopo da Reforma Administrativa, que a "reforma dos serviços públicos federais, centralizados e descentralizados, terá por fim último criar ou aperfeiçoar os instrumentos de pesquisa, previsão, planejamento, direção, execução, coordenação e contrôle de que carece 
o Poder Executivo para acelerar, harmoniosamente, em benefício do povo brasileiro, a consecução dos fins sociais do Estado, de progresso social, desenvolvimento econômico e bem-estar geral, definidos na Constituição e nas Leis".

No artigo 2, o Chefe do Poder Executivo afirma: "A ur gência da Reforma Administrativa decorre, sobretudo, do imperativo de modernizar e tecnificar o sistema de órgãos integrantes do Poder Executivo da União, com o propósito expresso de transformá-lo em puderoso propulsor do desenvolvimento economico $e$ social".

Tendo a Reforma Administrativa êsses objetivos, essa urgência e essa importância, determina o Presidente da República, no artigo seguinte, que "os estudos e pesquisas que se realizarem para instruir a Reforma Administrativa serão orientados no sentido de identificar as causas de ineficiência, desperdício, inadequação e obsoletismo funcionais, resultantes seja da estrutura, seja do funcionamento dos serviços públicos federais".

Vê-se que o Poder Executivo classifica a Reforma Administrativa entre as reformas essenciais. E' de se crer que o Poder Legislativo, ao qual serão submetidos, a partir de abril do corrente ano, os Anteprojetos de Lei veiculadores de propostas da Reforma Administrativa, não titubeará em fazer causa comum com o Poder Executivo, e que receberá, estudará, tramitará e votará tais Projetos como partes integrantes, indissociáveis, de uma das reformas de base reclamadas pelo povo brasileiro.

\section{DIRETRIZES GERAIS}

Além das diretrizes particulares constantes das seções próprias dêste Plano, os Grupos de Estudo e Reforma estabelecidos e os que vierem a ser criados deverão afeiçoar as respectivas tarefas, no que lhes fôr aplicável, às Diretrizes Gerais que se seguem.

\section{I — DEPARTAMENTALIZAÇÃo}

A divisão dos Ministérios não deverá descer além do nível departamental. Cada Projeto de Lei que tratar de estrutura ministerial explicará ùnicamente as divisões primárias - departamentos, conselhos e órgãos equivalentes. As divisões secundárias e terciárias serão estabelecidas em regulamentos e regimentos internos por Decreto do Poder Executivo.

A tradição brasileira apresenta múltiplos exemplos de Leis Orgânicas extremamente minuciosas e casuisticas, que chegam a especificar as atribuições de chefes de seção, porteiros etc. Tra- 
ta-se de prática nociva. Onerar o tempo e as atenções dos representantes do povo na Câmara dos Deputados e no Senado Federal com legislação administrativa representa desperdício de recursos sociais. A divisão dos órgãos primários dos Ministérios em unidades menores, geralmente chamadas divisões, serviços, secções, etc., é tarefá pré-executiva, e, portanto, da competéncia do Poder Executivo. Do nivel departamental para baixo, a estruturação dos órgãos confunde-se com a própria divisão do trabalho, cabendo, assim, ao Poder Executivo fixar, alterar, desdobrar, abolir, denominar, amalgamar, em regulamentos e regimentos internos, as unidades administrativas menores integrantes das secretarias, departamentos e conselhos.

A erradicação de nossa tradição casuística oferece vantagens evidentes. A tramitação de Leis Orgânicas gerais, que indiquem apenas a divisão primária dos órgãos, poupa aos legisladores o esfôrço ancilar de deliberar sôbre unidades administrativas de importância secundária, que devem ser criadas ou modificadas consoante as necessidades domésticas do Poder Executivo. O progresso tec11ológiç determina o obsoletismo de muitos órgâos e gera a necessidade de unidades novas, exigindo ajustamentos freqüentes, que fazem impraticável a apreciação pelas Câmaras Legislativas das pequenas modificações desejadas. A dinâmica da administração moderna torna imperativo que as recomposições internas fiquem a cargo dos próprios órgãos executivos.

A questão da direção de órgãos secundários não caracterizados na Lei resolver-se-á mediante o recurso da criação, pelo Congresso, de determinado número de cargos de chefia intermediária, os quais serão posteriormente distribuídos e redistribuídos pelo Poder Executivo, de acôrdo com as conveniências do serviço e as necessidades de cada Ministério. Em certos casos, o Poder Executivo recorrerá, supletivamente, à criação de simples funções gratificadas para atender à remuneração dos ocupantes de lugares de chefia das unidades operacionais menores (divisões, serviços, seções etc.). Isso dará aos órgãos do Poder Executivo a flexibilidade de que necessitam, e que devem ter, para se adaptar às condições cambiantes da administração moderna. E' a prática dos paises mais desenvolvidos e mais bem administrados, tanto parlamentaristas quanto presidencialistas, como a Suécia, a Inglaterra, os Estados Unidos, o Canadá etc.

Em diversos departamentos ministeriais há unidades administrativas de somenos importância, hipertrofiadas ou atrofiadas, que se eternizam no orçamento e no organismo público. Havendo sido criadas por Lei, sòmente por Lei podem ser abolidas, modificadas ou retificadas. E' intuitivo que nâo se deve usar o tormidável mecanismo do Poder Legislativo, de que atualmente parti- 
cipam cêrca de 500 legisladores e centenas de funcionários pertencentes à Câmara dos Deputados e ao Senado, para deliberar sôbre a divisão inteına das repartições ministerials. E' evidente, no caso, a desproporção entre a envergadura do Legislativo e a insignificância do objeto.

\section{II - PARCIMÔNIA}

Um dos principios gerais encarecidamente recomendados aos Grupos de Estudo e Reforma é a parcimônia na criação de órgãos, sobretudo de órgãos que acarretem criação de cargos. O objetivo dominante da reforma administrativa é melhorar os coeficientes de eficiência do serviço público. Isso implica aumento de rendimento e, simultâneamente, redução de gastos. Recomenda-se, pois, aos Grupos de Estudo que se abstenham de propor a criação de qualquer órgão de necessidade menos premente. Sòmente nos raros casos de necessidade evidente, comprovada exaustivamente, demonstrada além de tôda dúvida possivel, poderá ser examinada a criação de órgãos novos. Ainda nesses casos, será conveniente justificá-la com a extinção ou reclução de órgãos existentes. A finalidade desta recomendação é evitar, tanto quanto possivel, aumento de despesas com a engrenagem administrativa da União.

Mesmo no caso de desdobramento de algum Ministério, o que o Ministro Extraordinário para a Reforma Administrativa sòmente endossará quando se tratar de proposta sòlidamente justificada, - é recomendável extrema sobriedade nas iniciativas que puderem provocar aumento de despesa. A Reforma Administrativa deverá ser uma redistribuição racional de recursos, principalmente de pessoal, não um veículo para criação de novos ônus públicos.

\section{III -- DESCENTRALIZAÇ̃̃o DA EXECUÇ̃̃o}

Outro principio guiador da Reforma Administrativa é o da descentralização. A execução das tarefas administrativas $e$ as decisões imediatas que ela envolve devem ficar a cargo das autoridades descentralizadas e ocorrer nos próprios locais de trabalho, pouco importando que êstes estejam territorialmente situados a milhares de quilometros das unidades gerais a que pertençam. E' preciso que a transferência da responsabilidade leve consigo a correspondente dose de autoridade. Num país como o Brasil, especialmente, em que a diversidade de graus e de desenvolvimento e as dimensões continentais de território complicam a ação administrativa, não se compreendem as práticas centralizadoras, às vêzes patológicas, contumazes no serviço público federal. A cen- 
tralização administrativa é responsável pelo congestionamento da Presidência da República, dos gabinetes ministeriais e dos gabinetes dos diretores de órgãos de jurisdição nacional.

\section{IV - CENTRALIZAÇÃo DO CONTRÔLE}

Paralelamente à descentralização da execução, é necessário institucionalizar a centralização do contrôle. Os órgãos de formulação de politica e decisão, como a Secretaria da Presidência da República, os Gabinetes dos Ministros de Estado e os órgãos correspondentes dos Departamentos, Conselhos etc., devem estar capacitados para proceder deliberada e sistemàticamente ao contrôle de tôdas as dependências subordinadas. Fixadas as normas gerais, aprovados os planos de trabalho e distribuidas as tarefas e responsabilidades, os órgãos de decisão e comando devem estar imediatamente habilitados a exercer vigilância permanente sôbre os órgãos subordinados, a fim de evitar desvios, aceleraçöes e retardamentos indesejados na execução das ordens. Cabe-lhes captar, inclusive, as possíveis definições e interpretações distorsivas das ordens dadas. A verificação metódica, pelas autoridades superiores, do cumprimento das instruções expedidas, o confronto do planejado com o executado e demais tarefas de contrôle devem ser executados ostensivamente, como parte regular das funções do Presidente da República, dos Ministros de Estado e de todos os diretores de órgãos que tenham jurisdição nacional.

\section{$\mathrm{V}$ - LINHAS GERAIS}

Os Grupos de Estudo deverão timbrar em definir, nos projetos de reforma, apenas os lineamentos gerais dos órgãos reformados. Cumpre-lhes evitar as inclinações detalhistas, e deixar os pormenores para a legislação subordinada. Unidades de Organização e Métodos ou Grupos de 'Trabalho especialmente criados cuidarão de identificar e fixar, a seu tempo, já na órbita do Executivo, as minúcias operacionais de cada Ministério, por meio de regulamentos, regimentos internos, instruções de serviço, manuais de trabalho e dispostivos assemelhados.

\section{VI - ALCANCE DO CONTRÔLE VERSUS HOMOGENEIDADE}

Aos Grupos de Estudo e Reforma é sugerido que, na tarefa de agregar e desdobrar órgãos, o pragmatismo, o bom senso e a "lei da situação" devem prevalecer sôbre os princípios abstratos e as teorizações livrescas. Sendo possivel conciliar os chamados principios da homogeneidade e do alcance do contrôle, tanto melhor. Não sendo, a escolha deverá pender para o principio 
que melhor se ajustar às circunstâncias. E' admissivel até a ccorrência de casos em que o organizador terá que transgredir, deliberadamente, ao mesmo tempo, os dois princípios. Ao subordinar, por exemplo, maior número de órgãos algo heterogêneos a um chefe, a fim de evitar a multiplicidade de chefias especializadas, - e com elas o encompridamento da escala hierárquica e a complexidade da coordenação - o organizador estará violando, simultâneamente, os dois principios.

Em tarefas de organização e reorganızação, as instâncias mais freqüentes, porém, são aquelas em que o reformador ou é levado a ignorar o principio do alcance do contrôle, a fim de obedecer ao da homogeneidade, ou, para não transgredir crassamente o primeiro, é forçado a desdobrar órgãos de conteúdo profissional homogêneo, mas demasiado numerosos.

Numa organização altamente especializada, que disponha de pessoal técnico idôneo em todos os seus setores, é possivel, talvez desejável, rigorismo na observância simultânea dêsses dois princípios antagônicos. Entanto, tratando-se do sistema administrativo brasileiro, parece prudente atender mais ao princípio do alcance do contrôle, e menos ao da homogeneidade, a fim de prevenir a proliferação de departamentos, divisões e órgãos superespecializados, para muitos dos quais nosso mercado de trabalho ainda não oferece os quadros técnicos correspondentes. Ficando entendido, todavia, que, nos casos de órgãos que envolvam especializações e categorias profissionais universalmente reconhecidás e bem caracterizadas, como, por exemplo, os médicos, os contadores, os arquitetos, os agrônomos, o princípio da homogeneldade deve primar sôbre o do alcance do contrôle.

$\mathrm{Na}$ grande maioria das vêzes, o critério pragmatista, baseado naquilo a que os americanos chamam horse-sense, ainda é o guia preferivel.

\section{VII — DIREÇÃO UNIPESSOAL VERSUS DIREÇÃO COLEGIAL}

Tanto no que concerne aos órgãos executivos quanto aos assessoriais, preferência deve ser dada à direção unipessoal. A experiência de outros paises, fortemente corroborada pela brasileira, contra-indica a existência de órgãos executivos de direção colegial. Mesmo os órgãos predominantemente assessoriais funcionam melhor sob direção unipessoal. O Presidente da República, os Ministros de Estado e, de modo geral, todos os diretores de departamento de jurisdição nacional necessitam de órgãos assessoriais, mas êstes devem ser dirigidos, em regra, por uma só pessoa, não sujeitos às discussões de grupos deliberativos. 


\section{VIII - RESISTÊNCIA À AUTARQUIZAÇÃO}

Há quem responsabilize o Código de Contabilidade e, até certo ponto, o Tribunal de Contas pela proliferação das autarquias e, ùltimamente, das emprêsas públicas e sociedades de economia mista. Para muitos observadores, já há demasiadas autarquias, demasiadas emprêsas públicas e sociedades de economia mista no Brasil, tôdas competindo entre si e com o Govêrno Federal nos mercados de trabalho, de material etc. E' preciso resistir à tendência generalizada para a autarquização. Há Ministérios cujos serviços e dependências já se encontram, quase todos, ou autarquizados ou em processo de autarquização.

O comportamento das autarquias e de várias emprêsas públicas criadas nos últimos vinte anos comprova que a proclamada eficiência dessas entidades deixa muito a desejar. Basta dizer que, de dois têrços a três quartos do deficit da União, coberto mediante emissões de papel-moeda e endividamento, correspondem aos deficits somados de autarquias e emprêsas públicas criadas sob o pretexto de se tornarem financeiramente auto-suficientes.

Tenhamos, pois, extremo cuidado no estudo de qualquer proposta de criação de novas autarquias. A apreciação algébrica das autarquias brasileiras (tarefa interessante e que precisa de ser levada a efeito) possivelmente viria evidenciar vultoso saldo negativo. Torna-se, portanto, cada vez menos consistente o argumento da eficiência a que se tem recorrido para justificar as propostas de autarquização.

Os Grupos de Estudo e Reforma intuirão que, no momento, quando a fase autarquizante parece estar no apogeu, propostas de desautarquização, mesmo bem fundamentadas, não seriam oportunas, nem viáveis. Incumbe-nos evitar, porém, que se criem novas autarquias e sociedades mistas sob o patrocínio da Reforma Administrativa, a menos que estudos exaustivos e irrespondiveis venham a demonstrar a insubsistência desta diretriz.

\section{IX - SIMPLICIDADE}

No estabelecimento da estrutura dos Ministérios, os Grupos de Estudo e Reforma deverão optar pelos critérios mais simples de departamentalização. Os chamados departamentos de clientela sòmente deverão ser propostos em casos especiais, exaustivamente justificados. Os departamentos de processo, por sua vez, deverão ser restritos aos usos tradicionais, dando-se preferência, na maioria dos casos, aos departamentos de propósito, e, para fins de descentralização, aos de base geográfica.

Tratando-se de uma reforma de grande envergadura, que enreda em suas malhas todos os órgãos do Poder Executivo, 
convém que os reformadores se acautelem contra as novidades pouco testadas e, sobretudo, as transplantações clamorosas.

Nos casos de dúvida, devemos preferir os tipos de organização tradicionais e as denominações simples e significativas. Cumpre ter sempre presente que os tipos de órgãos, suas designações e funções não devem constituir motivo de perplexidade para o público. Por exemplo: um Departamento de Pesquisas Cientificas pode ser fonte permanente de ministério para o povo em geral, ao passo que um Serviço de Cambate à Lepra explica, desde logo, sua significação e finalidade pela própria clareza do nome.

\section{$\mathrm{X}$ - PESQUiSA, PI.ANEJAMENTO E CONTRÔLE}

Os órgãos executivos integrantes do sistema administrativo da União carecem de unidade de pesquisa, planejamento e contrôle. A administração pública brasileira necessita de descobrir e praticar as virtudes da pesquisa, tanto para fins de planejamento, quanto para atividades de contrôle dos resultados. Necessita, igualmente, de implantar o planejamento em todos os niveis hierárquicos, como fase administrativa compulsória. Nenhum ato praticado por servidor público deverá ser fruto da improvisação, mas emanar de decisões prévias, amadurecidas e articuladas em planos. Não se trata aqui de planejamento econômico, exclusidade de economistas, nem de planejamento físico, exclusividade de engenheiros e arquitetos, mas de planejamento governamental global, que se caracteriza pela fusão de vários planos setoriais e parciais em planos gerais.

O contrôle é complementar ao planejamento. Planeja-se para dar racionalidade ao trabalho. Controla-se para assegurar a execução dos planos. A intelectualização do processo administrativo está, assim, condicionada à existência de órgãos idôneos de pesquisa, planejamento e contrôle.

Se a Reforma Administrativa lograr implantar e institucionalizar, nos órgãos componentes do Poder Executivo, a pesquisa, o planejamento e o contrôle, terá justificado abundantemente todos os esforços e canseiras.

\section{DIRETRIZES ESPECIFICAS PARA OS GRUPOS DE ESTUDO E REFORMA}

I - GRUPO DE ESTUDO E REFORMA DA PRESIDÊNCIA DA REPÚBLICA

Dadas a magnitude dos interêsses coletivos insatisfeitos, as pressões dos diferentes segmentos da população e a inquietação 
social provocada pela consciência do subdesenvolvimento, a presente conjuntura brasileira exige dos podêres públicos, particularmente do Govêrno Federal, esforços inauditos na luta pela solução de problemas acumulados, muitos dos quais deveriam ter sido resolvidos, normalmente, pelo menos há duas gerações.

Por sua eminência e poderio, a Chefia Executiva da República é o centro para o qual refluem as reinvidicações, os anseios $e$ as esperanças, e contra o qual também se voltam os primeiros impulsos de impaciência, os desapontamentos, as frustrações, as revoltas das várias camadas da sociedade. $\mathrm{Na}$ verdade, uma decisão da Chefia Executiva pode ter as repercussões mais profundas, positivas ou negativos, e afetar gerações inteiras.

A tentativa do neoparlamentarismo e o retôrno do País ao presidencialismo pela via do plebiscito vieram realçar, ainda mais, a responsabilidade da Presidência da República. Cumpre que o supremo órgão de comando do Poder Executivo esteja aparelhado para enfrentar os problemas mais diversos, descobrir as soluções mais imaginosas e eficazes, numa palavra, desempenhar os encargos da liderança política e administrativa do País.

Dentre os vícios e defeitos de que padece o sistema administrativo federal, os especialistas que o têm estudado são unânimes em apontar o congestionamento da Presidência da República. Em sete decênios e meio de existência, a Presidência da República acolheu e acumulou, em sua órbita estrutural, sem os assimilar, numerosos órgãos que, em vez de contribuirem para a eficiência executiva, concorrem para a dispersão e a desordem. São unânimes os estudiosos em apontar a necessidade de medidas que assegurem à Presidência da República a estrutura ordodoxa de uma Chefia Executiva moderna.

A fim de exercer as funções próprias da Chefia Executiva, a Presidência da República necessita desvencilhar-se de relações diretas com os órgãos, serviços, comissões e autarquias a ela agregados, em diferentes épocas, por motivos vários, inclusive a insciência administrativa, embora jamais houvesse razões doutrinárias, lógicas ou pragmáticas para tal subordinação.

Além disso, parece aconselhável reajustar e completar o sistema de órgãos auxiliares, uns de assessoramento, outros de execução, de que a suprema Chefia Executiva carece para funcionar satisfatòriamente como centro de liderança, propulsão e contrôle dos órgãos do Poder Executivo.

As unidades integrantes da Presidência da República porveritura incompletas, hipertrofiadas, arcaizantes ou mal ajustadas devem sofrer as modificações indispensáveis, para que funcionem cono um todo orgânico, bem articulado, inteiramente capacitado, do ponto-de-vista profissional e funcional, a prestar ao 
Chefe do Estado os serviços chamados de Estado-Maior. Queixam-se os titulares da Presidência da República da massa ingente de trabalhos repetitivos e secundários, meros atos rotineiros, que lhes são submetidos à assinatura (não à apreciação), roubanäo-lhes tempo e atenções que deveriam ser utilizados no estudo, análise e decisão de assuntos importantes.

A tarefa a cargo do Grupo de Estudo e Reforma da Presi dência da República, apesar de restrita à área da Chefia Executiva, apresenta-se como parte essencial da Reforma Administrativa.

O Brasil atravessa um periodo de grande intensidade histórica, em que a luta pelo desenvolvimento econômico assume cada dia aspectos novos e dramáticos. Da Presidência da República depende, em larga escala, a frutificação dos esforços que estão sendo feitos, e que deverão ser redobrados, nos próximos decênios, em favor de nosso emancipação econômica.

E' preciso audácia para propor e coragem para aceitar as medidas que, aparentemente radicais no que concerne à estrutura e funcionamento da Presidência da República, se fizerem imprescindiveis para dar ao País um órgão de comando executivo à altura das tremendas exigências e contradições atuais.

\section{II — GRUPO DE ESTUDO E REFORMA DO MINISTÉRIO DA FAZENDA}

Os estudos referentes à reforma do Ministério da Fazenda deverão orientar-se, originàriamente, no sentido da criação de duas Secretarias de Estado: uma para cuidar dos negócios fazendários, outra para cuidar dos assuntos econômicos, notadamente os de moeda e crédito.

Esforços serão envidados a fim de reunir, confrontar e analisar todos os projetos e propostas feitos nos últimos 10 anos para alterar a estrutura e funcionamento do Ministério da Fazenda. A organização que se propuser para êste Ministério deverá estar condicionada ao imperativo de torná-lo um organismo fiscal moderno, de grande sensibilidade, capaz de impedir a sonegação e a evasão de impostos, assim como o contrabando e o descaminho. Em sua nova organização, to Ministério da Fazenda deverá ser o grande instrumento do Govêrno para combater a perpetuação dos deficits orçamentários. Cada cidadão deve contribuir proporcionalmente à respectiva renda para o custeio aos serviços públicos. Ȧ União cabe arrecadar até o último ceitil, de todos os contribuintes, sem qualquer distinção, os impostos e taxas. E' na exação rigorosa das leis tributárias, na capacidade do Fisco Federal para se impor ao respeito e ao temor dos contribuintes, que se encontra uma das chaves do contrôle da inflação monetária. 
De todos os serviços gerais da União, aquêle cuja remodelação se impõe, como necessidade imperiosa, é o da arrecadação dos impostos e taxas. Falhando o Fisco, o Govêrno Federal não poderá financiar, sem recorrer à emissão de papel-moeda e aos empréstimos, os Ministérios e demais entidades incumbidas de realizar os fins do Estado. A reforma do aparelho arrecadador do Ministério da Fazenda, objeto de um contrato entre aquela Secretaria de Estado e a Fundação Getúlio Vargas, não deverá ser simples ajustamento de órgãos e divisão de trabalho, mas uma revisão profunda de métodos, modernização de tôda a engrenagem fiscal e seu equipamento, incluindo programas de treinamento e retreinamento do quadro de servidores, enfim, uma mobilização dos recursos técnicos e doutrinários disponiveis, para que o Ministério desempenhe cabalmente as funções de financiador das atividades públicas e regulador dos problemas econômicos que lhe estão afetos.

\section{III - GRUPO DE ESTUDO E REFORMA DO MINISTÉRIO DA JUSTIÇA E NEGÓCIOS INTERIORES}

Os estudos referentes à reforma do Ministério da Justiça e Negócios Interiores deverão orientar-se no sentido de demonstrar a conveniência ou inconveniência de ser aceita a proposta apresentada à Presidência da República, em 1959, pela Comissão de Estudos e Projetos Administrativos (C.E.P.A.), de seu desdobramento em dois Ministérios distintos, a saber: o Ministério da Justiça e o Ministério do Interior.

A C.E.P.A. foi enfática ao recomendar a dicotomização do Ministério da Justiça e Interior, chegando a afirmar que, de tôdas as suas propostas, nenhuma lhe parecia mais justificada. E argumentava: "Com efeito, que similitude pode haver entre os negócios da Justiça e, digamos, por exemplo, a administração territorial? Se, entre os atuais, há um Ministério cuja composição viole flagrantemente o principio da homogeneidade, é o Ministério da Justiça e Negócios Interiores. Seu desdobramento em dois Ministérios, nos têrmos propostos pela C.E.P.A., representa progresso considerável".

Como setor dos negócios públicos, a Justiça é importante demais para que seus serviços e interêsses não sejam cuidados com exclusividade por uma Secretaria de Estado. Por outro lado, os negócios do Interior, como a proteção aos indios, a administração territorial e os que hoje estão afetos ao Instituto Brasileiro de Geografia e Estatística, à Superintendência do Plano de Valorização Econômica da Amazônia, etc., representam, também, setor não menos importante da administração pública. Acaso não 
requerem, para seu tratamento exclusivo, uma Secretaria de Estado?

O Ministério do Interior seria a Secretaria de Estado de que o Poder Executivo carece para integrar, gerir, orientar e dinamizar os órgãos de desenvolvimento regional, como a Superintendência do Plano de Valorização Econômica da Amazônia, a Superintendência do Desenvolvimento do Nordeste, e outras da mesma familia.

A significação da reforma do Ministério da Justiça é ainda encarecida pelo fato de envolver o Departamento Federal de Segurança Pública - peça basilar do sistema administrativo da União.

A transferência da sede do Govêrno para Brasilia veio dar maior relêvo à necessidade da criação de um sistema nacional de polícia. Certas infrações penais repercutem em diferentes pontos do território nacional, ou alastram-se por várias unidades da Federação, exigindo uniformidade de repressão, cooperação das instituições policiais e serviços rápidos e fidedignos de telecomunicação. No Estado Federal, não é possivel reprimir o contrabando, o descaminho, os crimes contra a fé pública, o roubo e furto de veículos automóveis, o rapto e seqüestro de pessoas, e outras infrações assemelhadas sem um aparelhamento idôneo de âmbito nacional.

A reestruturação do Departamento Federal da Segurança Pública representa uma preocupação constante do Govêrno da União. Ao Grupo de Estudo e Reforma do Ministério da Justiça cabe dispensar cuidados especiais à situação institucional precária com que luta o. Departamento. Convém que o Grupo se informe sôbre os trabalhos das Comissões Especiais criadas em 1961, pelo então Ministro da Justiça e Negócios Interiores, para propor a reestruturação do Departamento Federal de Segurança Pública e a criação do Departamento Federal de Imigração.

No caso de optar pelo desdobramento do Ministério, o Grupo deverá examinar os órgãos de outros Ministérios, notadamente do Ministério da Viação e Obras Públicas, que passariam a integrar o Ministério do Interior. Se criado, é provável que o Ministério do Interior venha a incluir em sua estrutura, de acôrdo com o principio da homogeneidade, órgãos, serviços e autarquias atualmente pertencentes ou vinculadas à Presidência da República, ao Ministério da Viação, ao da Agricultura etc.

IV - GRUPO DE ESTUDO E REFORMA DO MINISTÉRIO

DA INDÚSTRIA E COMÉRCIO

A Lei $n^{\circ} 3.782$, de 22 de julho de 1960, transformou o antigo Ministério do Trabalho, Indústria e Comércio no atual 
Ministério do Trabalho e Previdência Social e criou, simultâneamente, com partes desmembradas daquele, o Ministério da Indústria e Comércio, instalado em 1961.

A criação dêste Ministério era necessária e foi oportuna, talvez tenha sido retardada além do razoável. A experiência brasileira de 30 anos consecutivos provara, conclusivamente, que a centralização dos problemas da indústria e comércio com os do trabalho, previdência e assistência social em um só Ministério, acarreta a negligência dos primeiros e assegura o primado dos segundos.

Em seù Relatório Final, publicado pelo Departamento de Imprensa Nacional em 1963, a Comissão de Estudos e Projetos Administrativos diz a respeito: "Era imprescindível que o desenvolvimento industrial e comercial do Brasil fôsse orientado por uma Secretaria de Estado homogênea, em que os interêsses da indústria e do comércio, naquilo em que coincidissem com os interêsses gerais do Pais, constituíssem preocupação dominante, senão exclusiva".

UIma vez que o nôvo Ministério foi instalado há apenas dois anos, é provável que tão curta existência ainda não haja revelado as possiveis falhas de estrutura, sobretudo no que diz respeito às atividades funcionais (fins). Vale dizer, contudo, que a Lei $n^{\circ} 3.782$ apresenta a singularidade de ser omissa no que toca às atividades institucionais (meios) - pesquisa administrativa, planejaniento, organização, pessoal, orçamento, material, comunicaçõ $:$, patrimônio, documentação. Em outras palavras, a Lei não deu ao Ministério da Indústria e Comércio as condições mínimas para ser administrado, uma vez que não tinha órgão de administração geral.

Pusteriormente, o Congresso decretou a Lei n 4.048, de 29 de dezembro de 1961, que dispõe sôbre a organização do Ministério da Indústria e Comércio. Essa lei departamentaliza o Ministério e cria um órgão de administração geral, nos moldes dos existentes nos demais Ministérios civis. Pelos Decretos números 531, 532, 533, 534 e 535, todos de 23 de janeiro de 1962 , o Presidente do Conselho de Ministros de então aprovou e baixou - Regulamento do Ministério da Indústria e Comércio e os Regimentos dos órgãos integrantes, completando, assim, a organização formal daquela Secretaria de Estado.

A preocupação maior do Grupo de Estudo e Reforma do Ministério da Indústria e Comércio deverá consistir em verificar, pois, mediante pesquisa idônea, se a estrutura atual do Ministério corresponde às suas finalidades, e se a sua vida institucional está assegurada pelas medidas postas em prática depois da adoção 
da Lei n' 3.782. Cumpre a êste Grupo responder, especificamente, entre outras, à seguinte pergunta: Está o Ministério da Indústria e Comércio organizacionalmente capacitado para prover aos meios administrativas necessários ao seu pleno funcionamento?

\section{V - GRUPO DE ESTUDO E REFORMA DO MINISTÉRIO}

DAS MINAS E ENERGIA

O simples confronto do número de expedientes submetidos à Chefia Executiva pelos diferentes Ministérios no periodo neoparlamentarista compreendido entre 8 de setembro de 1961 e 30 de junho de 1962 demonstra que o Ministério das Minas e Energia estava encontrando sérias dificuldades para funcionar. Com efeito, ao passo que a média de expediente dos demais Ministérios era de 74 por mês, no caso do Ministério das Minas e Energia a média não foi além de 7 por mês. Tendo a seu cargo todos os problemas de aproveitamento do subsolo e suas riquezas, assim como as questões de energia, num país continental como o Brasil, e numa fase de franca expansão dessas atividades, não se comprénde que o Ministério das Minas e Energia, funcionando em pé de igualdade com os demais Ministérios, tivesse tão pouccas questões para submeter à Chefia Executiva. Que explica essa disparidade de comportamento ministerial?

Parece que a explicação se encontra no fato de haver o Ministério das Minas e Energia sido criado, exatamente como o Ministério da Indústria e Comércio, sem órgãos administrativos. As chamadas atividades institucionais (meios) não podiam ser regularmente exercidas no Ministério das Minas e Energia, porque êste carecia de órgãos especificos para exercê-las.

Cumpre ao Grupo de Estudo e Reforma do Ministério das Minas e Energia examinar, em primeiro lugar, as condições administrativas do Ministério, a fim de completar, se fòr o caso, a sua estrutura; em segundo lugar, a parte relativa às atividades funcionais (fins).

$E^{\prime}$ possivel que seja cedo para tratar da reorganização do Ministério das Minas e Energia. Este ainda não dispôs de tempo. para testar suficientemente sua estrutura. Mas, no que diz respeito à parte administrativa, que é a que proporciona os meios para a consecução dos fins, cumpre ac Grupo reformador proceder a verificações completas sôbre o funcionamento do órgão. $\mathrm{E}^{\prime}$ indispensável que se lhe dê um departamento de administração geral, organizado e lotado de tal modo que o Ministério não deixe de realizar as suas finalidades por caquexia administrativa. 


\section{VI - GRUPO DE ESTUDO E REFORMA DO MINISTÉRIO} DO TRABALHO E, PREVIDÊNCIA SOCIAL

O Ministério do Trabalho e Previdência Social formou-se, em 1960, com a parte residual do antigo Ministério do Trabalho, Indústria e Comércio. Trata-se, assim, de uma Secretaria de Estado que tem a seu cargo os assuntos e problemas relacionados com a proteção geral ao trabalhador, a fiscalização das leis trabalhistas e a supervisão das atividades previdenciárias.

Dentre as modificações aventadas para o Ministério do Trabalho e Previdência Social, cumpre destacar duas: a primeira inclina-se para a dicotomização do Ministério, surgindo dêle dois Ministérios novos: o Ministério do Trabalho e o Ministério da Previdência Social; a segunda, menos radical, advoga a criação de duas Secretarias de Estado, que seriam dirigidas por Subministros de Estado e cuidariam, cada qual no seu setor, dos assuntos e problemas trabalhistas e dos assuntos e problemas previdenciais e assistenciais.

O Brasil goza do crédito de pioneirismo, na América Latina, em matéria de seguro social e proteção ao trabalhador. Além do Ministério do Trabalho, o Brasil criou e vem experimentando uma série de autarquias, que mobilizam centenas de bilhões de cruzeiros por ano para tratar das questões assistenciais e previdenciárias em favor das classes trabaihadoras. Levando-se em conta o volume dos recursos e atividades envolvidos e a numerosidade das clientelas, pode conjecturar-se que o atual Ministério do Trabalho e Previdência Social encerra substância bastante para explicar o desdobramento. Êsse argumento deve ser, entretanto, contrastado à luz de várias possíveis contra-indicações, como sejam, entre outras, a proliferação de novos Ministérios e o advento de Ministérios integrados exclusivamente por autarquias, o que, à primeira vista, pode parecer menos justificável.

O Grupo de Estudo e Reforma do Ministério do Trabalho terá, assim, que sopesar os prós e os contras das soluções aventadas e propor, com abundância de argumentos e fatos bem interpretados, a que lhe parecer mais consentânea com os interêsses coletivos. Cumpre-lhe não perder de vista que a Previdência Social, com seu numerosos institutos autárquicos, suas duplicações e seus paralelismos, a despeito da unidade fundamental dos objetivos, constitui um dos setores cruciais da Reforma Administrativa.

VII -- GRUPO DE ESTUDO E REFORMA DO MINISTÉRIO

DA VIAÇÃO E OBRAS PÚBLICAS

Pela extensão territorial e pelo efetivo demográfico, o Brasil parece requerer um Ministério dos Transportes e um Ministério 
das Comunicações. Sendo um Pais-Continente e que deverá estar totalmente ocupado, no curso dos próximos decênios, pelos novos contingentes demográficos que incorpora todos os anos, o Brasil necessita desesperadamente de resolver o problema crônico dos transportes. E' indispensável garantir e facilitar a mobilidade de pessoas e coisas, ao longo e através de seu território. Parece não haver dúvida de que, por sua envergadura, por sua complexida le técnica e pelo vulto de recursos que exige, o problema nacional dos transportes justifica, sem maior exame, a existência de um ministério exclusivamente dedicado à sua solução.

A comunicação é irmã siamesa do transporte. Se êste facilita a mobilidade de pessoas e coisas, aquela facilita a circulação de idéias e notícias, umas e outras se entrosando no complexo econômico-social, para alimentar as correntes comerciais e os movimentos culturais. O problema nacional das comunicações, conseqüentemente, num país tão extenso e que já conta com mais de 70 milhões de habitantes, que são outros tantos clientes ou usuários da rêde de comunicações, sugere a criação de um Ministério exclusivo para tratar de suas múltiplas facêtas.

Pelas modificações havidas na instrumentalidade dos transportes e comunicações no Brasil, pela autarquização de vários de seus órgãos componentes, pela descentralização dos serviços de obras, e, ainda, pelas tendências da Administração Federal, o atual Ministério đa Viação e Obras Públicas é, talvez, uma das unidades mais arcaicas de nosso sistema administrativo. Sua denominação, particularmente, já perdeu a razão de ser.

Partindo dêsses pressupostos, os estudos concernentes à reforma do Ministério da Viação e Obras Públicas deverão orientar-se no sentido de investigar a conveniência ou a contra-indicação de seu desdobramento em dois Ministérios novos. Mas, naturalmente, caberá ao Grupo de Estudo e Reforma do Ministério da Viação avaliar e demonstrar as vantagens e desvantagens das modificações propostas ou aventadas, e formular seus projetos e recomendações de acôrdo com o que the parecer mais concorde com os interêsses gerais do País.

VIII - GRUPO DE ESTUDO E REFORMA DE MINISTÉRIO DA AGRICULTURA

O Ministério da Agricultura acaba de passar por uma reforma. Seu Regimento atual é de data muito recente: foi baixado com o Decreto n: 51.701, de 11 de fevereiro de 1962 .

A inoperância tradicional do Ministério da Agricultura explica, pelo menos em parte, a proliferação de órgãos como a COFAP, o Conselho Coordenador do Abastecimento e, ùltimamente, a SUNAB e a SUPRA, e certos órgãos mistos, como o 
ETA, todos criados e mantidos para cuidar de aspectos particulares do problema do abastecimento.

Nem na fase em que o Brasil se considerava "um país essencialmente agrícola" desempenhou o Ministério da Agricultura o papel que lhe competia de guia e estimulador das atividades agropecuárias, de modo que estas se expandissem e se consolidassem equilibradamente, atualizando-se, acompanhando o progresso tecnológico.

Os estudos relativos à nova estrutura e ao funcionamento do Ministério da Agricultura deverão ser conduzidos no sentido de responder a perguntas como estas: A recente reforma do Ministério da Agricultura foi realística? Criou para aquêle órgão condições propicias ao seu funcionamento satisfatório, sobretudo numa fase em que os problemas de abastecimento se sucedem e se agravam? A recente reforma do Ministério da Agricultura harmoniza-se com a filosofia da Reforma Administrativa geral? Há necessidade de se fazerem ajustamentos no Ministério da Agricultura, pequenos ou grandes, a fim de enquadrá-lo na Reforma Administrativa geral?

\section{IX - GRUPO DE ESTUDO E REFORMA DO MINISTÉRIO DAS RELAÇÕES EXTERIORES}

O Ministérios das Relações Exteriores também foi recentemente reorganizado (Lei n? 3.917, de 14 de julho de 1961), coincidindo a reforma, cronològicamente, com o período em que o Brasil submetia sua politica exterior a um processo de revisão. Ao lado da Índia, da Austrália e do Canadá, o Brasil começa a aparecer no cenário internacional como potência média em ascensão. Se ainda não chegou à posição de "país decisivo", pelo menos já se vem desvencilhando da situação de país secundário. Com a afirmação de sua personalidade internacional cada vez mais vigorosa, crescem paralelamente as responsabilidades do Brasil como nação independente, democrática e em luta pelo desenvolvimento. O processo de cristalização da politica exterior do Brasil consolidar-se-á tanto mais depressa quanto mais cedo conquis tarmos nossa emancipação econômica. Para desempenhar essa tárefa, o Govêrno requer um órgão altamente sensivel e afinado para captar, analisar, interpretar os acontecimentos significativos e ajustar a política exterior do Brasil ao desenrolar dos negócios internacionais, tendo em mente, acima e antes de tudo, os interêsses nacionais. A politica exterior do Brasil deve ser um instrumento eficiente de defesa e promoção de nossos interêsses.

Tem-se afirmado que o Ministério das Relações Exteriores possui excelente quadro de pessoal, graças, sobretudo, ao sistema do mérito que há vários anos pratica. $O$ ingresso na carreira 
diplomática brasileira, há mais de 15 anos, vem-se fazendo, invariàvelmente, por meio de concurso público, ou de cursos ministrados pelo Instituto Rio Branco, onde o ingresso é, igualmente, precedido de concurso público.

Os estudos referentes à reforma do Ministério das Relações Exteriores deverão orientar-se no sentido de identificar os possiveis pontos falhos existentes na reforma de 1961. E' provável que o pequeno prazo decorrido após a adoção daquela reforma não seja suficiente para permitir a identificação de suas virtudes ou defeitos, demasias ou falhas. O Grupo de Estudo e Reforma do Ministério das Relações Exteriores deverá diligenciar, assim, após exame meticuloso das alternativas, se fôr o caso, para propor, corajosamente, ou nova reforma, ou ajustamento na reforma recente.

\section{$X$ - GRUPO DE ESTUDO E REFORMA DO MINISTÉRIO \\ DA EDUCAÇÃo E CULTURA}

Nenhum confronto dos indices culturais per capita do Brasil com os dos demais países da América Latina nos pode deixar eufóricos. Em matéria de alfabetização, o Brasil oscila entre o décimo e o décimo-primeiro lugar. Segundo os dados publicados pela UNESCO e constantes do volume Faits et Chiffres (Paris. 1958), o Brasil ocupa, na América Latina, o nono lugar na tiragem diária de jornais por 1.000 habitantes, o sexto no consumo de papel de jornal por habitante, o oitavo em número de receptores de rádio existentes por 1.000 habitantes, o terceiro na produção total de filmes de longa metragem, o quarto na freqüência anual dos cinemas por habitantes. No que se refere ao número de médicos por grupos de habitantes, similarmente, a situação do Brasil não é melhor, figurando nosso pais em nono lugar.

Dada a existência de condições comuns aos países latinoamericanos, é de se indagar: por que o progresso relativo alcancado por outros paises do Continente, em matéria de ensino, não se verificou também no Brasil?

O Ministério da Educação e Cultura é o principal instrumento até hoje criado no Brasil para promover a difusão do ensino e assegurar a formação das categorias profissionais, cientificas e especializadas de que necessitamos.

Não há negar que as atividades educacionais do Pais, sobretudo aquelas diretamente superintendidas pelo Ministério da Educação e Cultura, têm crescido nos últimos anos em ritmo animador. Criado e m1932, com o nome de Ministério da Educação e Saúde Pública, e desdobrado em 1953, quando se criou o Ministério da Saŭde com órgãos até então pertencentes ao primeiro, e dado o advento da Lei de Diretrizes e Bases, aprovada em 1961, o atual 
Ministério da Educação e Cultura requer, entretanto, exame meticuloso, que compreenda tanto a estrutura e o funcionamento, quanto os métodos e normas de trabalho.

Conforme foi dito na Introdução dêste trabalho, há disparidade flagrante entre o elenco técnico-profissional de que o Brasil necessita, estimado em 1.500 .000 individuos, e aquêle de que efetivamente dispõe, cêrca de 200.000 individuos. Algo deve ser feito, com urgência, relativamente ao sistema educacional. Numa fase em que o Brasil tanto se preocupa com o progresso econômico, não se admitem braços cruzados, nem providências tíbias no que diz respeito ao desenvolvimento de seus recursos humanos. Os estudos concernentes ao Ministério da Educação e Cultura, para efeito de reforma, deverão ser copiosos e exaustivos. Ao anteprojetar a reforma do Ministério da Educação e Cultura, é indispensável que se utilizem todos os recursos doutrinários e pragmáticos disponiveis, que as experiências de outros países sejam analisadas e que o diagnóstico das falhas de nosso sistema educacional prime pelo realismo. E' imperativo que o Brasil descubra, e ponha a serviço de seu ensino, métodos de trabalho e critérios que assegurem rendimento progressivo às atividades do Ministério da Educação e Cultura.

\section{XI - GRUPO DE ESTUDO E REFORMA DO MINISTÉRIO DA SAÚDE}

Manda a justiça reconhecer que os nossos serviços de saúde pública apresentam um acervo de realizações brilhantes e alvissareiras. A erradicação da febre amarela, no Rio de Janeiro primeiro, e, depois, em todo o Brasil, o contrôle da peste bubônica, as campanhas da malária e de outras endemias rurais assomam na história administrativa do Brasil como conquistas meritórias, que recomendariam os serviços de saüde pública de qualquer país. Muitas dessas realizaçốes, entretanto, são anteriores ao advento do Ministério da Saúde, embora êste haja herdado, merecidamente, o crédito acumulado a partir do comêço do século pelos nossos serviços de saúde pública.

Cumpre registrar e proclamar, também, que tanto a duração média da vida do homem brasileiro tem aumentado quanto a mortalidade infantil tem diminuído, sobretudo a partir do fim da Segunda Guerra Mundial. Fatôres diversos contribuíram e contribuem para êsse resultado: a elevação do nivel geral de cultura, o progresso do state of arts, a radiodifusão, a educação sanitária, a melhoria das condiçóes de vida de grande parte do povo etc.

Mas o Ministério da Saúde, neste país, que há menos de uma geração aceitava, passivamente, o rótulo deprimente de "vasto hospital", e que ainda hoje está longe de oferecer proteção real à saúde de seus habitantes, tem sôbre os ombros tarefas fofrmidá- 
vel, tendente a tornar-se ainda mais árdua, na medida em que, com a elevação do nível cultural e a politização das massas, estas se fizerem mais esclarecidas e mais reinvindicativas, cada qual diligenciando receber os serviços indivisiveis de saúde pública, como a profilaxia geral, e também os serviços tangiveis, como a assistência médico-hospitalar.

De todos os Ministérios, o da Saúde é o que tem maior clientela. Os contingentes de população, que o Brasil incorpora todos os meses por meio da natalidade, somente virão a constituir clientela do Ministério da Educação, por exemplo, vários anos depois, e uma vez saido da escola, por conclusão de curso ou por qualquer outra causa, o individuo deixa de constituir problema para o Ministério da Educação. Mas, cada habitante do País, desde que nasce até que morre, e mesmo antes de nascer e depois de morrer, é um problema para o Ministério da Saúde Eis por que, no Brasil, a organização dêste Ministério oferece maiores dificuldades técnicas do que a de outros: trata-se de um órgão que deve estar preparado para receber, todos os dias, encargos mais volumosos. Em 1963, a clientela do Ministério da Saúde compor-se-á de 74 milhões de individuos; em 1965, já terá âumentado para cêrca de 80 milhões. Pcr outro lado, os assuntos e encargos afetos a êste Ministério prendem-se às necessidades básicas do individuo. Quer dizer, a ação protetora do Ministério da Saúde não podé ser adiada - tem caráter de imprescindibilidade imediata.

E' preciso, pois, mobilizar tôda a argúcia e competência dos integrantes dêste Grupo de Estudo. Cabe-lhes a responsabilidade de descobrir, ou inventar, uma estrutura satisfatória, assim como indicar os melhores métodos de trabalho para o Ministério da Saúde.

Comparados com a magnitude da tarefa a que se destinam, os recursos orçamentários do Ministério da Saúde são provadamente insuficientes. Dada a natureza de suas funções, necessita o Ministério de utilizar, mais do que qualquer outro, todos os dispositivos e artifícios de organização do trabalho que contribuam para o aumento da eficiência.

As pesquisas e estudos relativos à estrutura e ao funcionamento dêste Ministério deverão ser orientados no sentido de identificar e fundamentar aquelas alterações certas e seguras, destinadas a ensejar uma fase áurea de realizações para o Ministério da Saúde. O problema da assistência médico-hospitalar estatal, especialmente a que é ministrada pelas instituições de previdência social e que absorve parcelas mais e mais vultosas de recursos humanos e materiais, parece exigir atenção especial por parte do Grupo de Estudo e Reforma do Ministério da Saúde. 
XII - GRUPO DE ESTUDO E ORGANIZACC.ÃO ADMINISTRATIVA DO DISTRITO FEDERAL

Capital nova, concebida e levantada em bases revolucionárias, Brasilia necessita de $11 \mathrm{ma}$ estrutura administrativa inteiramente ajustada a seus designios. E' indispensável que as entidades constituídas para a construção e desenvolvimento de Brasilia tenham sua organização rigorosamente adaptada à necessidade de manter e acelerar o ritmo das obras de acabamento da cidade. Sua tarefa crucial é completar e ampliar a série de serviços urbanos indispensáveis ao funcionamento pleno de Brasilia. Seria desastroso, por exemplo, que as instituições criadas para o fim de erigir a nova Capital se transformassem em quartéisgenerais de empreguismo e passassem a consumir as suas energias em busca de recursos para pagar o pessoal, ao invés de empregá-las na conclusão da tarefa. Ninguém questionará o fato de ser Brasilia motivo de orgulho do urbanismo latino-americano, mas cabe não obscurecer os sacrifícios ingentes que o Pais fêz para financiar a sua construção.

Os estudos e pesquisas que se realizarem para o fim de identificar e fundamentar a estrutura ideal dos serviços públicos municipais do Distrito Federal devem ser realisticamente guiados pela finalidade última de Brasilia. Como Capital Federal, Brasília precisa de adquirir condições para desempenhar o seu papeI de centro administrativo de propulsão do progresso econômico e social do Pais. Cumpre a Brasilia não ser apenas uma nova fronteira geográfica, em que se expandem as criações da nova arquitetura brasileira. E' preciso que seja também uma nova fronteira administrativa, de onde deverá irradiar o exemplo da boa gerência dos negócios públicos. Além de conhecimentos especializados, muita imaginação, audácia criadora, patriotismo, documentação abundante e idônea devem ser utilizados na contextura dos trabalhos entregues a êste Grupo de Estudo. Para que Brasilia seja Capital modêlo, é indispensável que possua administração modelar.

\section{XIII - GRUPO DE ESTUDO E ELABORAÇÃO DE NORMAS ORÇAMENTÁRIAS E FINANCEIRAS}

Urge retificar o processo de elaboração da Lei de Meios. Pecando por excesso de discriminação, a Proposta Orçamentária Federal provoca milhares de emendas, tumultua o Congresso e deforma o quadro geral das atividades governamentais, tanto das rotineiras quanto das novas. Cumpre entender, formular e executar o Orçamento como dispostivo de planejamento e contrôle 
a serviço do Poder Executivo, não como cornucópia de benesses financeiras e distribuições paroquialistas.

A Comissão de Estudos e Projetos Administrativos (C.E.P.A.) submeteu ao Presidente da República, em 1959, um projeto de normas para elaboração, execução e contrôle orçamentários. Exis. te, por outro lado, em fase de aprovação no Congresso Nacional, - Projeto de Lei $n^{\circ} 38$, de 1962, que institui normas gerais para elaboração dos Orçamentos da União, dos Estados, dos Municipios e do Distrito Federal. Trata-se, nos dois casos, de subsidios valiosos, que condensam muitas e muitas horas de estudos e discussões de grupos de especialistas e interessados. E' provável que o projeto em tramitação no Congresso Nacional seja aprovado antes da conclusão dos trabalhos dêste Grupo de Estudo, assim como é possivel que o Grupo verifique a desnecessidade de novos projetos, dada a hipótese de aquêle atender às exigências da administração federal.

Segundo o Relatório prévio sôbre as contas da União correspondentes ao exercicio de 1961, apresentado ao Tribunal de Contas da União por um de seus membros, apenas $29 \%$ das despesas realizadas no referido exercicio financeiro foram processados regularmente. O grosso, nada menos de $71 \%$, representava despesas cujo processamento havia transgredido uma ou mais normas legais.

O problema do contrôle efetivo dos gastos da administração indireta deverá merecer cuidados especiais por parte dêste Grupo de Estudo. Das dezenas de autarquias federais existentes, a que o Govêrno da União delegou setores inteiros dè suas responsabilidades sociais, raras são as que submetem as contas à perquirição do Tribunal de Contas. Nestes últimos dez anos, das poucas que cumprem a Lei e a ética administrativa, e têm apresentado contas ao Tribunal de Contas, apenas uma ou outra consegue aprovação para as mesmas, tais as irregularidades que infestam a respectiva documentação.

De tal modo tem sido negligenciado o processo de tomada de contas, e notadamente a obrigação de prestar contas por parte dos responsáveis pela aplicação dos dinheiros públicos, que não há exagêro em afirmar-se que a tarefa confiada ao Grupo de Normas Orçamentárias e Financeiras, além de representar uma das mais árduas e complicadas, representa ao mesmo tempc, uma das mais importantes da Reforma Administrativa. Seria truísmo repetir que o desembôlso dos dinheiros públicos deve ser feito com método e ordem, obedecidas rigorosamente as normas pertinentes que a experiência administrativa universal já desenvolveu. A Reforma Administrativa, em que estão empenhados o Poder Executivo e o Congresso Nacional e em que o povo brasileiro 
deposita vivas esperanças, falhará a uma de suas principais finalidades se não descobrir solução técnica para o problema do contrôle orçamentário, financeiro e legal dos gastos públicos.

As despesas conjuntas da União, suas autarquias, emprêsas públicas e sociedades de economia mista já introduziram uma grandeza astronômica, inaudita - o trilhão de cruzeiros — na contabilidade pública e nos relatórios financeiros. E' imperativo submeter essa avalancha de gastos à disciplina do contrôle efetivo. Os Podêres Públicos precisam curvar-se, submissos, à obrigação de acatar as normas éticas e legais relativas ao emprêgo dos recursos sociais a êles confiados. Em suma: cumpre adotar normas e procedimentos que protejam, ao mesmo tempo, os dinheiros públicos dos desvios intencionais, dos desperdicios, das malversações e das apropriações indébitas, e as autoridades honestas que os desembolsam, das desconfianças e suspeitas baseadas em rumôres, nas aparências e nas similitudes.

\section{XIV - GRUPO DE ESTUDO E ELABORAÇÃO DE NORMAS PARA IMPLANTAÇÃO E INSTITUCIONALIZAÇÃO}

\section{DO PLANEJAMENTO}

Temos feito progresso em matéria de planejamento parcial, sobretudo no setor econômico. Cabe-nos marchar para a fase mais avançada e fecunda, que é a do planejamento governamental global, em que os planos parciais são sopesados, ajustados e integrados em planos gerais, e êstes passam a constituir os terms of reference do Govêrno. Uma das caracteristicas dessa fase do planejamento governamental é a coincidência dos orçamentos com as etapas anuais dos planos de longa duração. Em outras palavras, cada orçamento passa a representar, nada mais, nada menos, do que a especificação atual de reccursos financeiros destinados ao custeio da etapa correspondente do plano geral em execução.

A Comissão de Estudos e Projetos Administrativos inclui, entre suas recomendações finais, o estabelecimento, pelos órgãos integrantes do Poder Executivo, mormente a Presidência da República e os Ministérios, de um sistema de planejamento encarregado de pesquisar a fundo os fatos administrativos e planejar com base no conhecimento objetivo, completo e verificado, as atividades a curto e longo prazo de cada órgão ministerial, e de combinar os planos parciais, finalmente, num plano geral orgânico, de longa duração, dividido em etapas anuais coincidentes com o exercício financeiro.

Diz o relatório da C.E.P.A. que a faflha mais grave do Projeto de Lei da Reforma Administrativa (refere-se ao Projeto em tramitação no Congresșo Nacional desde agôsto de 1953) é, precisamente, a omissão de um sistema de órgãos e práticas que, 
enredando tôda a administração federal, tivesse a responsabilidade expressa de planejar as atividades governamentais.

Em outra parte, a C.E.P.A. recomenda que, entre os deveres regulamentares taxativos dos diretores de serviço, de chefes de divisão para cima, se incluam as de elaborar, fundamentar e propor planos periódicos de trabalho para as respectivas unidades. E' preciso pôr têrmo à improvisação na conduta dos negócios públicos. Cumpre criar um clima institucional a um tempo propício à prática do planejamento e hostil à improvisação. E' preciso forçar os nossos executivos a pensarem sistemàticamente, a curto e a longo prazo, no trabalho futuro de suas repartições. $\mathrm{E}^{\prime}$ preciso proteger os recursos sociais contra a utilização enipirica, ao sabor de circunstâncias ocasionais, e que tanto desperdicio tem causado no serviço público do País.

Nessas considerações da C.E.P.A. encontramos, sem dúvida, as diretrizes para os estudos que se procederem com a finalidade de propor providências destinadas à implantação e institucionalização do planejamento no serviço público brasileiro.

\section{XV - GRUPO DE ESTUDO E ELABORAÇÃO DE NORMAS PARA PRESERVAÇÃO E REVIGORAMENTO DO SISTEMA DO MÉRITO}

Em seu Relatório Final, a Comissão de Estudos e Projetos Administrativos recomendou que o sistema do mérito fôsse expandido em tôda a administração federal, de modo que, inclusive os órgãos de chefia, mesmo em comissão, e as promoções passassem a depender, em todos os casos, de apuração de merecimento, pelos melhores métodos conhecidos, a fim de que os postos de maior responsabilidade e aquêles cujas funções demandassem maiores conhecimentos e experiência fôssem providos, invariàvelmente, pelos mais capazes.

"E' desejável - diz o Relatório da C.E.P.A. - que o serviço público federal adote uma clarividente politica de pessoal com o objetivo deliberado e notório de atrair os melhores candidatos existentes no mercado de trabalho e reter os melhores servidores".

Em outra passagem diz a C.E.P.A. que, à margem os exemplos confortadores do Ministério das Relações Exteriores e do DASP, a politica de pessoal e salarial do Govêrno não tem tido a virtude de atrair para o seu serviço as melhores cabeças, as melhores competências profissionais e os melhores talentos administrativos que surgem no mercado de trabalho. Entretanto, os negócios mais importantes, de cujo bom encaminhamento e gerência dependem o bem-estar, a segurança econômica e o desenvolvimento cultural do povo brasileiro, estão entregues ao serviço 
público federal em conjunto e distribuem-se, por igual, entre todos os Ministérios. Adotado o critério de confiar os negócios públi$\cos$ aos homens e mulheres de inteligência mais poderosa, formação profissional mais completa e talento administrativo mais penetrante, é certo que o serviço público brasileiro avançará, ràpidamente, para a conquista da reputação e do nivel de excelência compativeis com a sua relevância social. A preservação e o revigoramento do sistema do mérito deverão ter o propósito precipuo de elevar o conteúdo profissional e funcional do serviço público .

Êste Grupo de Estudos deverá, pois, ter presente, em tôdas as suas lucubrações, o objetivo final do sistema do mérito, que é atrair para o serviço público, e nêle reter, a nata profissional e os talentos de escol de cada geração.

\section{XVI - GRUPO DE ESTUDO E REVISÃO DE NORMAS E MÉTODOS DE TRABALHO DA ADMINISTRAÇÃO FEDERAL}

Aqui, também, podemos buscar no Relatório Final da C.E.P.A. subsídios para orientar o Grupo de Trabalho incumbido de proceder à revisão geral das normas e métodos de trabalho da Administração Federal. A C.E.P.A. recomenda que o Govêrno Federal organize a desfeche uma campanha, com ramificações em todos os Ministérios, autarquias, conselhos e comissões, para identificar e erradicar as rotinas arcaicas e os movimentos inúteis, os quais alongam os chamados canais competentes, geram a cadeia sem fim dos despachos interlocutórios, intumescem os processos e retardam os efeitos práticos das decisões e atos administratıvos.

Especificamente, a C.E.P.A. recomenda que se estabeleça um sistema de grupos de trabalho formados por pessoas entendidas em Organização e Métodos, articulados sob a orientação da Divisão de Orçamento e Organização do DASP, a fim de levantar as rotinas obsoletas, descobrir as etapas inúteis e elaborar manuais de operação tendentes a introduzir no serviço público os métodos simplificados vigorantes nos serviços públicos de cutros países e, especialmente, nas emprêsas particulares bem administradas. Cumpre que a administração federal disponha de grupos de funcionários capacitados para distinguir entre o útil e o inútil nos registros, nas etapas interlocutórias, na emissão de cópias e vias, enfim, naquela tramitação dos papéis oficiais que constitui a tessitura viva do dia-a-dia da administração.

Atenção especial deverá ser dada ao princípio geral da descentralização executiva conjugado com o da centralização do contrôle. E' desejável a existência, na Presidência da República e nas adjacências dos Ministros, de órgãos de alto teor profissional, capacitados para formular diretrizes e elaborar normas desti- 
nadas a orientar, condicionar e controlar, linha hierárquica abaixo, as atividades de todos os serviços e dependências subordinados. Paralelamente, é aconselhável a existência de órgãos incumbidos de velar pelo rigoroso cumprimento das diretrizes adotadas, assim como pela aplicação das normas expedidas. Obedecidos os princípios combinados da descentralização executiva e da centralização do contrôle, as pontes de comando da administração federal libertar-se-ão das avalanchas de rotinas dispersas e esterilizantes, podendo exercer à plenitude as funções que lhes são próprias de centros de captação dos anseios e necessidades do Pais e de estimulação e orientação dos órgãos executivos.

Esta deve ser a filosofia guiadora dos trabalhos afetos ao Grupo, certamente dos mais importantes, responsável pelo anteprojeto ou anteprojetos de normas e métodos de trabalho da Administração Federal.

\section{XVII - GRUPO DE ESTUDO E REVISÃO DA POLÍTICA SALARIAL}

A ausência de uma politica salarial, que, se observa no Serviço Público da União, inclusive e principalmente nas autarquias, emprêsas públicas e sociedades mistas, constitui um dos problemas mais complicados da Reforma Administrativa. O estudo dêste problema poderá intranqüilizar interêsses criados, que se solidarizam para defender a manutenção dos privilégios atuais e até estimular a expansão da anarquia dominante, certamente favorável a determinados grupos.

A proliferação das autarquias, primeiro, e mais recentemente, das sociedades de economia mista, tem influído para aumentar a desordem salarial reinante. Gozando de autonomia orçamentária e financeira, e carecendo de um corpo de doutrina e um conjunto de regras para lhes disciplinar os problemas de pessoal, algumas autarquias, as emprêsas públicas e as sociedades de economia mista têm concorrido com a sua diversidade de critérios de remuneração para balburdiar o problema salarial do serviço público. Além disso, podendo estabelecer vencimentos e salários mais liberais do que os órgãos da administração direta, os serviços ẹstatais autônomos e paraestatais, embora alguns dêles utilizem recursos do Tesouro, como no caso das autarquias e sociedades de economia mista cujos deficits são cobertos anualmente pela União, movem concorrência desleal ao próprio Govêrno no mercado de trabalho, já atraindo os jovens mais talentosos, já recrutando servidores dos próprios quadros do serviço civil tradicional. Ao passar a servir em órgão autônomo ou paraestatal como requisitado ou sob outra forma, o funcionário passa também a auferir vencimentos superiores aos que correspondem a seu cargo no serviço civil tradicional da União. 
Por outro lado, a autonomia financeira e administrativa permite às autarquias, emprêsas públicas e sociedades de economia reajustarem prontamente os vencimentos dos seus servidores sem intervenção do Congresso Nacional, o que, nestes últimos anos. de inflação acentuada, também representa um atrativo a mais, tornando mais cobiçado o emprêgo nos órgãos de administração. indireta. Servidores cujos vencimentos são pagos com dinheiro do Tesouro Nacional, uns servindo nos Ministérios, outros nas autarquias e emprêsas públicas, embora desempenhem funções iguais e até exerçam cargos de denominação igual, percebem vencimentos dispares, havendo casos em que os que servem nas autarquias e emprêsas assemelhadas chegam a receber até o dôbro do que receberiam se fôssem do serviço civil tradicional da União. Isso representa violação frontal e crassa da regra elementar de administração de pessoal que manda que se dê remuneração igual aos que desempenham funções iguais, em condições de trabalho idênticas. A desigualdade de remuneração no Serviço Público Federal é múltipla e notória: pode ser copiosamente documentada mediante confrontos e comparações entre os salários correspondentes às mesmas categorias de cargos e aos mesmos grupos profissionais, a serviço dos Ministérios e das autarquias.

O sistema de remuneração composto de parte fixa e outra variável, oscilando a variável segundo o incremento da arrecadação, produz, por sua vez, resultados embaraçosos e até grotescos do ponto-de-vista administrativo, como seja, por exemplo, o caso de servidores que chegam a receber até o dôbro dos vencimentos dos Ministros de Estado.

As pesquisas, estudos e propostas referentes à reformulação de politica salarial do Govêrno devem ser orientados com o objetivo de sugerir normas gerais de remuneração que evitem de um lado situações iníquas para qualquer grupo de servidores, e, de outro lado, normalizem situações privilegiadas de que gozam outros grupos. Trata-se de um problema técnico de avaliação de cargos, de maneira que os titulares das diferentes carreiras sejam enquadrados segundo critérios impessoais, de acôrdo com normas prefixadas, e nunca ao sabor dos exagêros, das ambições e das pressões de grupos organizados para promoção dos seus interêsses à custa dos interêsses gerais. O serviço civil de carreira deve, certamente, oferecer condições materiais satisfatórias para atrair os melhores candidatos do mercado de trabalho e reter nos quadros públicos os melhores servidores. Como empregador, porém, - Estado não deve adotar escalas de salários diferentes, muito menos dar tratamento preferencial a qualquer grupo de empregados. A ética e a razão contra-indicam escalas de salários preferenciais, as quais constituem privilégios para a minoria e desestímulo para a maioria. 
Em seu Relatório Final, a Comissão de Estudos e Projetos Administrativos inclui a seguinte recomendação:

“A C.E.P.A. recomenda a abolição radical do sistema de remuneração composto de uma parte fixa e outra variável de que gozam certos grupos privilegiados de servidores públicos.

"O sistema nada mais representa do que uma sobrevivência antidemocrática de costumes medievais, quando os tributos eram vendidos ou arrematados por prepostos e validos, ficando êstes com podêres discricionários para extorquí-los dos contribuintes. No Brasil, a justificativa para a manutenção e expansão do sistema retrógrado, primitivo e insustentável, - porque garante privilégios de mandarins a certas minorias de servidores públicos transformando-os em sócios do Tesouro Público - tem sido a alegação de que a participação no crescimento das receitas públicas estimula os fiscais e exatores a excelirem no desempenho de suas funções.

"O argumento é especioso. Em primeiro lugar, porque singulariza determinada classe de servidores como grupo que necessita de remuneração adicional e polpuda para cumprir $o$ dever. Em segundo lugar, porque os países que mais aprimoram seus métodos de combate ao contrabando e à sonegação de impostos, como a Inglaterra, os Estados Unidos e o Canadá, não tiveram necessidade de dar participação no aumento da arrecadação e do produto das multas aos agentes do fisco. A sociedade dos agentes do fisco no produto da arrecadação dos impostos representa atraso deplorável.

"Os fatos de nossa vida administrativa rea! infirmam frontalmente a validade do argumento em que repousa o sistema de remuneração privilegiada. Apesar de dar aos exatores e fiscais anipla participação no aumento das rendas e no produto das multas, o Brasil não se avantaja a nenhum pais do mundo em matéria de administração fiscal. Ao contrário, nivela-se com aquêles em que o contrabando campeia e a scnegação de impostos só não chega a ser escândalo público porque sua incidência tem caráter endêmico.

"Por que então manter o privilégio para certos grupos de servidores, que não prestam serviços, nen melhores, nem maiores, nem mais complexos, do que, por exemplo, os generais, os professôres, os médicos, os engenheiros? Em nome de que fundamentos éticos, racionais ou pragmáticos se justificam remunerações várias vêzes superiores às de quaisquer outras classes de funcionários da União?

"Na moderna administração de pessoal, os critérios de fixação dos níveis salariais baseiam-se universalmente na dificuldade das funções, nas responsabilidades envolvidas e na prepa- 
ração profissional. Os funcionários da União que gozam de privilégio de remuneração que às vêzes representa o décuplo do que percebe um professor universitário, não exercem funções prop̣rcionalmente mais dificeis, nem o exercício delas exige preparacĩo profissional proporcionadamente mais longa e profunda. São simplesmente beneficiários felizes de sobrevivências medievais, típicos interêsses criados, que se perpetuam disfarçados em direitos adquiridos".

Fica estabelecido o prazo de 90 dias, a contar da data da publicação da portaria que o instituir, para êste Grupo completar sua tarefa e submeter as respectivas propostas, recomenclações e anteprojetos ao Ministro Extraordinário para a Reforma Administrativa.

\section{XVHI — GRUPO DE ESTUDO E REORGANIZAÇÃO DO SISTEMA DE MATERIAL DO SERVIÇO CIVIL DA UNIÃO}

Em quase todos os países modernos os governos são os maiores empregadores, os maiores consumidores e os maiores compradores. O Brasil não foje à regra. Como comprador, o Govêrno Federal é a maior unidade existente no Pais. Os artigos de consumo, os equipamentos e os materiais de construção comprados pelo Govêrno da União em 1962, por exemplo, terão custado aos cofres públicos algumas centenas de bilhões de cruzeiros.

O vulto das compras governamentais comunica à administração de material importância extraordinária. Qualquer melhora introduzida nesse setor produz efeitos cumulativos consideráveis. Por exemplo: calcula-se que uma economia de apenas $2 \%$ na administração de material do Govêrno da União significaria, êste ano, de seis a sete bilhões de despesas a menos para os cofres públicos.

A administração de material no serviço público da União registrou progresso animador na década dos 30 . Criou-se o Departamento Federal de Compras, fêz-se a padronização e simplificação dos impressos, fixaram-se especificações tecnológicas, iniciou-se o contrôle do consumo. Chegou-se a articular e pôr em funcionamento o sistema de administração de material dos órgãos civis integrantes do Poder Executivo.

Nos últimos anos, entretanto, o sistema vem-se desagregando. Estancou-se o progresso, o Departamento Federal de Compras tem perdido terreno, as antigas práticas de compras fragmentárias e competitivas pelos próprios órgãos consumidores voltaram a ser ensaiadas. Em suma, o sistema de material do Serviço Civil da União não só não tem acompanhado a evolução do todo a 
que pertence, senão também revela índices de retrocesso. Os interêsses gerais do País demandam a reimplantação, ativação e ampliação de boas práticas de gerência de material.

E' objetivo e dever da Reforma Administrativa compilar, analisar, selecionar e consolidar, para o Serviço Público Civil da União, os principios, práticas, dispositivos e artifícios de adminis tração de material desenvolvidos e testados por governos e emprêsas particulares em busca de racionalidade e economia. Incumbe, pois, ao Grupo de Estudo e Reorganização do Sistema de Marterial reformular e propor normas operantes para reendereçar o sistema na via própria. A tarefa confiada a êste Grupo terá pontos de contato e, portanto, problemas de coordenação, com as tarefas de grupos afins, notadamente com os seguintes:

- Grupo de Estudo e Reforma da Presidência da República;

- Grupo de Estudo e Reforma do Ministério da Fazenda;

- Grupo de Estudo e Elaboração de Normas Orçamentárias e Financeiras;

- Grupo de Estudo e Elaboração de Normas para a Implantação do Planejamento;

- Grupo de Estudo e Revisão das Normas e Métodos de Trabalho da Administração.

XIX - COORDENADOR-GERAL DOS GRUPOS DE ESTUDO

O Ministro Extraordinário para a Reforma Administrativa designará um servidor para se incumbir da coordenação geral das atividades de todos os Grupos de Estudo já criados ou em vias de criação.

As atribuições do Coordenador-Geral serão fixadas pelo $\mathrm{Mi}$ nistro na portaria de designação.

\section{XX — GRUPO DE ASSESSÔRES GERAIS DA REFORMA ADMINISTRATIVA}

Haverá junto ao Ministro Extraordinário para a Reforma Administrativa um Grupo de Assessôres Gerais, composto de pessoas que se hajam distinguido pelos estudos e atividades no campo da Administração Pública.

Será responsabilidade dêsse Grupo rever, juntamente com o Ministro, aperfeiçoar o completar, quando fôr o caso, os anteprojetos e as recomendações emanados dos diferentes Grupos de Estudo. 